\title{
Fulvalenediyl-bridged heterobimetallic complexes consisting of sandwich and half-sandwich compounds with early-late transition metals
}

\author{
Alexander Jakob ${ }^{a}$, Petra Ecorchard ${ }^{a}$, Tobias Rüffer ${ }^{a}$, Michael Linseis ${ }^{b}$, Rainer F. Winter ${ }^{b, *}$, Heinrich Lang ${ }^{a, *}$ \\ ${ }^{a}$ Technische Universität Chemnitz, Fakultät für Naturwissenschaften, Institut für Chemie, Lehrstuhl für Anorganische Chemie, Straße der Nationen 62, 09111 Chemnitz, Germany \\ ${ }^{b}$ Universität Regensburg, Institut für Anorganische Chemie, Universitätsstraße 31, 93040 Regensburg, Germany
}

\begin{abstract}
A B S T R A C T
A straightforward synthesis methodology for the preparation of heterobimetallic $\left[\left(\eta^{5}-\mathrm{C}_{5} \mathrm{H}_{5}\right)\left(\eta^{5}-\mathrm{C}_{5} \mathrm{H}_{4-}\right.\right.$ $\left.\left.\mathrm{C}_{5} \mathrm{Me}_{4}\right) \mathrm{M}\right](3 \mathbf{a}, \mathrm{M}=\mathrm{Fe} ; 3 \mathbf{b}, \mathrm{M}=\mathrm{Ru})$ and $\left[\left(\eta^{5}-\mathrm{C}_{5} \mathrm{H}_{5}\right)\left(\left(\mu-\eta^{5}: \eta^{5}-\mathrm{C}_{5} \mathrm{H}_{4}-\mathrm{C}_{5} \mathrm{Me}_{4}\right) \mathrm{TiCl}_{3}\right) \mathrm{M}\right](\mathbf{4 a}, \mathrm{M}=\mathrm{Fe} ; \mathbf{4 b}$. $\mathrm{M}=\mathrm{Ru}$ ) in which early and late transition metals are connected by a fulvalenediyl bridge is reported.

The structures of molecules $\mathbf{3 b}$ and $\mathbf{4 a}$ in the solid state are discussed. Most noteworthy in $\mathbf{4 a}$ is the exo arrangement of the iron and titanium atoms coordinated by the fulvalenediyl unit which itself is twisted with a dihedral angle between the joined cyclopentadienyl rings of $19.33(9)^{\circ}$. Electrochemical, UV/Vis/ NIR spectroscopic and spectroelectrochemical experiments on $\mathbf{4 a}$ and $\mathrm{Cp} \mathrm{TiCl}_{3}$, for comparison, provide evidence for some transfer of electronic information between the conjoined ferrocene and half-sandwich titanocene trichloride subunits of 4a. Evidence comes from systematic potential shifts and the presence of a fairly intense $\mathrm{Fe} \rightarrow \mathrm{Ti}$ charge-transfer absorption band that vanishes upon oxidation and reduction of $4 a$.
\end{abstract}

\section{Introduction}

Homo- and heterobimetallic compounds in which two metal atoms are interconnected by conjoined cyclopentadienyl ligands have been studied in relation to metal-metal interactions because the appropriate transition metal centers are kept in close proximity by the organic linking group [1]. Such molecules are promising redox-active candidates with applications, for example, in multimetal catalysis and energy storage devices [2]. They also serve as starting compounds for the preparation of organometallic-based polymers and heteropolymetallics [3]. Many examples of metallocene-based homo- and heterobimetallic systems exist in which the two transition metals are linked by fulvalenediyl, fluorenediyl or indacenediyl moieties [4]. An example of a chiral heterobimetallic bis(fulvalenediyl) complex featuring early $(\mathrm{Zr})$ and late $(\mathrm{Fe})$ metal atoms from bis(cylopentadienyl)- and bis(indenyl)-substituted ferrocenes was reported by Brintzinger and coworkers [5]. Therefore, we set out to explore the possibility of synthesizing fulvalenediylbased heterobimetallic complexes with titanium(IV) and iron(II) or ruthenium(II) metal ions.

We describe here a straightforward synthesis methodology for the preparation of molecules of type $\left[\left(\eta^{5}-C_{5} \mathrm{H}_{5}\right)\left(\left(\mu-\eta^{5}: \eta^{5}-\mathrm{C}_{5} \mathrm{H}_{4^{-}}\right.\right.\right.$ $\left.\left.\left.\mathrm{C}_{5} \mathrm{Me}_{4}\right) \mathrm{TiCl}_{3}\right) \mathrm{M}\right](\mathrm{M}=\mathrm{Fe}, \mathrm{Ru})$. The electrochemical and UV/Vis/NIR

\footnotetext{
* Corresponding authors. Tel.: +49 371531 21210; fax: +49 37153121219.

E-mail addresses: rainer.winter@chemie.uni-regensburg.de (R.F. Winter) heinrich.lang@chemie.tu-chemnitz.de (H. Lang).
}

spectroelectrochemical behavior of $\mathbf{4 a}$ and $\mathrm{Cp}^{*} \mathrm{TiCl}_{3}$, for comparison, is reported as well.

\section{Results and discussion}

The synthesis strategy to prepare the title compounds is shown in Scheme 1. Our approach includes the reaction of monolithiated metallocenes $\left[\left(\eta^{5}-\mathrm{C}_{5} \mathrm{H}_{5}\right)\left(\eta^{5}-\mathrm{C}_{5} \mathrm{H}_{4} \mathrm{Li}\right) \mathrm{M}\right](\mathbf{1} \mathbf{a}, \mathrm{M}=\mathrm{Fe}: \mathbf{1 b}, \mathrm{M}=\mathrm{Ru})$ with 2,3,4,5-tetramethylcyclopent-2-enone (2) in a 1:1 molar ratio in tetrahydrofuran at $-80^{\circ} \mathrm{C}$ followed by acidic work-up and dehydration with para-toluenesulfonic acid. After appropriate work-up, the corresponding 2,3,4,5-tetramethylcyclopentadienyl-functionalized metallocenes $3 \mathbf{a}(\mathrm{M}=\mathrm{Fe})$ and $\mathbf{3 b}(\mathrm{M}=\mathrm{Ru})$, respectively, could be isolated as orange (3a) or yellow ( $\mathbf{3 b}$ ) solids in $78 \%$ yield. Molecules $\mathbf{3 a}$ and $\mathbf{3 b}$ were prepared in analogy to the synthesis route reported by Plenio [6] and Wan [4b].

Molecules $\mathbf{3 a}$ and $\mathbf{3 b}$ are the starting materials for the preparation of metallocene-based fulvalenediyl-bridged $\mathrm{Fe}-\mathrm{Ti}$ and $\mathrm{Ru}-\mathrm{Ti}$ complexes $\mathbf{4 a}$ and $\mathbf{4 b}$, respectively. Reaction of these compounds with "BuLi produced $\mathbf{L i}-3$ which on further treatment with $\mathrm{TiCl}_{4}$ in tetrahydrofuran at ambient temperature gave, after filtration through Celite and crystallization from dichloromethane/n-hexane mixtures $(1 / 10, v / v)$ at $-30^{\circ} \mathrm{C}$, the heterobimetallic compounds $\left[\left(\eta^{5}-C_{5} \mathrm{H}_{5}\right)\left(\left(\mu-\eta \eta^{5}: \eta^{5}-\mathrm{C}_{5} \mathrm{H}_{4}-\mathrm{C}_{5} \mathrm{Me}_{4}\right) \mathrm{TiCl}_{3}\right) \mathrm{M}\right] \quad(\mathbf{4 a}, \quad \mathrm{M}=\mathrm{Fe} ; \quad 4 \mathbf{b}$, $M=R u)$ in $33 \%$ or $50 \%$ yield. Compounds $4 a$ and $4 \mathbf{b}$ were obtained as intense green $(\mathbf{4 a})$ or purple $(\mathbf{4 b})$ solids, which are stable under inert gas atmosphere but decompose slowly on exposure to 


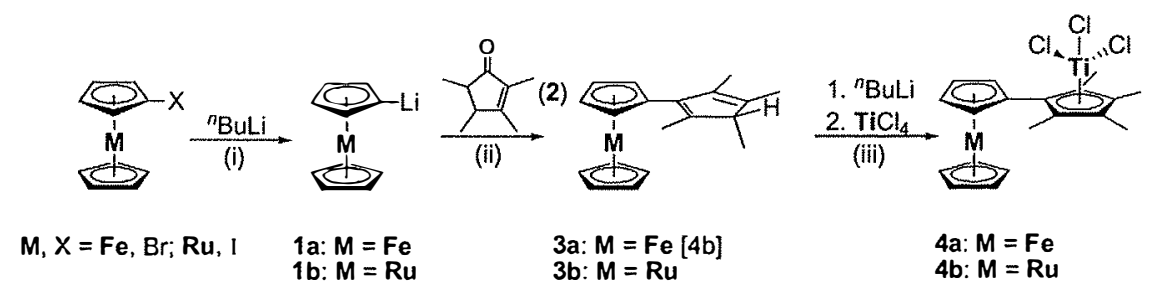

Scheme 1. Synthesis of heterobimetallic $4 a$ and $4 \mathbf{b}$ ((i) thf, $-80^{\circ} \mathrm{C}, 1 \mathrm{~h}$; (ii) thf, $-80^{\circ} \mathrm{C}, 1 \mathrm{~h} ;\left[\mathrm{NH}_{4}\right] \mathrm{Cl} / \mathrm{H}_{2} \mathrm{O}, 30$ min; p-toluenesulfonic acid, 30 min; (iii) $1 \mathrm{st}$ diethyl ether, $-30{ }^{\circ} \mathrm{C}$; $2 \mathrm{nd} \mathrm{TiCl}{ }_{4}$ diluted in $10 \mathrm{~mL}$ of toluene, $12 \mathrm{~h}$; please, notice that the preparation of $4 \mathrm{a}$ requires the presence of $\mathrm{PbCl}_{2}$ ).

moisture and air. They readily dissolve in common organic solvents including dichloromethane and tetrahydrofuran, while they are only sparingly soluble in hydrocarbon solvents. Complex $\mathbf{4 a}$ is dichroitic with a red or green color, depending on the angle of observation.

The spectroscopic data for 3 and $4\left({ }^{1} \mathrm{H},{ }^{13} \mathrm{C}\left\{{ }^{1} \mathrm{H}\right\}\right.$ NMR $)$ are consistent with their formulation as 2,3,4,5-tetramethylcyclopentadienyl-functionalized metallocenes and fulvalenediyl-bridged heterobimetallic systems (Section 2 ).

Good quality crystals of $\mathbf{3 b}$ were obtained by layering a diethyl ether solution containing $\mathbf{3 b}$ with $n$-hexane at $5{ }^{\circ} \mathrm{C}$, while the heterobimetallic Ti-Fe complex $\mathbf{4 a}$ was crystallized by layering a chloroform solution of $4 \mathrm{a}$ with $n$-pentane at $25^{\circ} \mathrm{C}$. Their structures in the solid state were determined by single X-ray diffraction studies (3b, Fig. 1; 4a, Fig. 2). Most important bond distances $(\AA)$ and bond angles $\left({ }^{\circ}\right)$ are summarized in the legends of Figs. 1 and 2. The crystal and structure refinement data are presented in Table 1 (Section 2).

Molecule $3 \mathbf{b}$ crystallizes in the space group $P 2_{1} / c$, $4 \mathbf{a}$ in the triclinic space group $P \overline{1}$. The molecular solid state structures of both compounds are consistent with their solution NMR data (Section 2). No unusual bond lengths and angles are observed (Figs. 1 and 2 ). The only notable feature of $\mathbf{3 b}$ is the $29.8(1)^{\circ}$ torsion of the cyclopentadienyl substituent $\mathrm{C} 11-\mathrm{C} 18$ with respect to the cyclopentadienyl ring $\mathrm{C} 1-\mathrm{C} 5$ of the ruthenocene moiety. In 4a the Fe 1 and Ti1 atoms are coordinated by the fulvalenediyl ligand in an exo arrangement. The fulvalenediyl unit is twisted with a dihedral angle of $19.33(9)^{\circ}$ between the individual cyclopentadienyl rings (Fig. 2). The ferrocene cylopentadienyl rings are eclipsed $\left(2.85(13)^{\circ}\right)$ and are parallel positioned to each other with a tilt

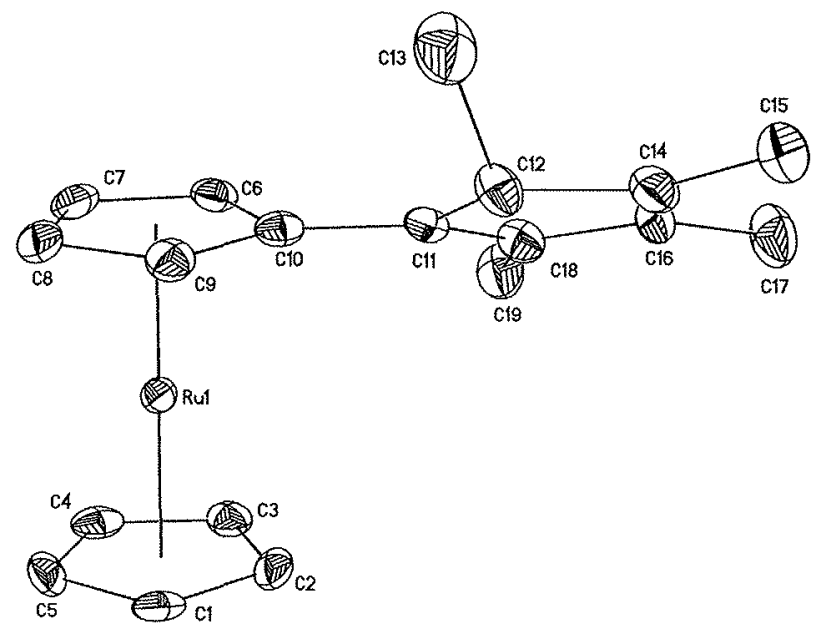

Fig. 1. ORTEP diagram ( $50 \%$ probability level) of the molecular structure of $3 \mathrm{~b}$ with the atom-numbering scheme. Hydrogen atoms have been omitted for clarity. Selected bond distances $(A)$ and bond angles $\left({ }^{\circ}\right)$ : Ru1-D1 1.818(2), Ru1-D2 1.811(1), C1-C11 1.462(5); D1-Ru1-D2 179.0. (D1 = centroid of C1-C5, D2 = centroid of $(6-\mathrm{C} 10)$

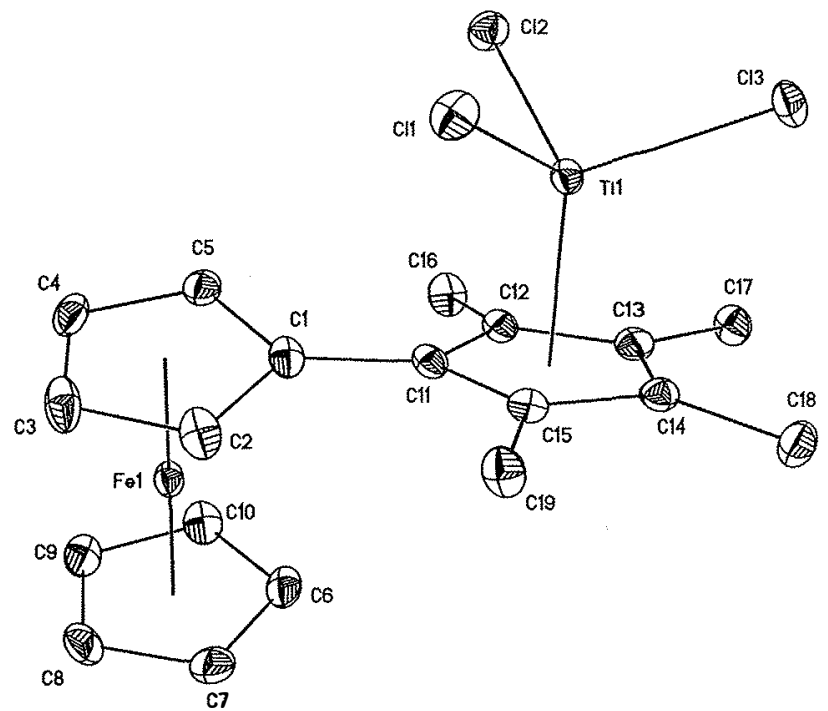

Fig. 2. ORTEP diagram ( $50 \%$ probability level) of $\mathbf{4 a}$ with the atom-numbering scheme. Hydrogen atoms are omitted for clarity. Selected bond distances $(\AA)$ and bond angles $\left({ }^{\circ}\right)$ : Fe1-D1 1.6442(13), Fe1-D2 1.6486(14), C1-C11 1.470(4), Ti1-D3 2.0274(13), Ti1-Cl1 2.2546(9), Ti1-Cl2 2.2452(9). Ti1-Cl3 2.2533(9); D1-Fe1-D2 178.00(8), D3-Ti1-Cl1 116.13(5), D3-Ti1-Cl2 115.84(5), D3-Ti1-Cl3 115.26(5). (D1 = centroid of C1-C5, D2 = centroid of C6-C10, D3 = centroid of C11-C15).

angle of $3.67(9)^{\circ}$. The titanium atom Ti1 in 4 a shows the expected three-legged piano-stool coordination [7], and is located 2.0274(13) $\AA$ above the plane of the $\eta^{5}$-bonded $\mathrm{C}_{5} \mathrm{Me}_{4}$ moiety (Fig. 2). In $4 a$ the iron and titanium atoms are separated by 5.3076(8) $\AA$ and are connected exo to the $\pi$-faces of a common $\pi$ conjugated hydrocarbyl ligand. Such arrangements are known to support magnetic and electronic interactions between the bridged sites as, for example, in biferrocenes [8], bis(trovacenes) [9], fulvalenediyl-bridged dimanganese and chromium complexes [10] or binickelocenes, -cobaltocenes and -vanadocenes [11]. Hence, complex 4a was exemplarily studied to obtain information about possible metal-metal ( $\mathrm{Fe}(\mathrm{II})-\mathrm{Ti}(\mathrm{IV})$ cooperative effects.

In cyclic voltammetry complex 4a shows the expected behavior of a reversible ferrocene-based oxidation and a close to reversible titanium-based reduction of the $\left(\eta^{5}-\mathrm{C}_{5} \mathrm{Me}_{4}-\mathrm{C}_{5} \mathrm{H}_{4}\right) \mathrm{TiCl}_{3}$ subunit (Fig. 3) [12]

Half wave potentials were determined as $0.140 \mathrm{~V}\left(\mathrm{Fe}^{\mathrm{II} / \mathrm{III}}\right)$ and $-1.110 \mathrm{~V}\left(\mathrm{Ti}^{\mathrm{iV} / \mathrm{III}}\right)$ against the ferrocene/ferrocenium scale. The $\mathrm{Fe}^{\mathrm{II} / \mathrm{III}}$ redox potential is $230 \mathrm{mV}$ positive of that of the first oxidation of biferrocene [14], while the titanium-based reduction occurs $20 \mathrm{mV}$ cathodic to that of $\mathrm{Cp}^{*} \mathrm{TiCl}_{3}\left(\mathrm{Cp}^{*}=\eta^{5}-\mathrm{C}_{5} \mathrm{Me}_{5}\right)\left(E_{1 / 2}=\right.$ $-1.130 \mathrm{~V}$ under our conditions). This indicates that the cyclopentadienyl $\mathrm{TiCl}_{3}$ subunit of $4 \mathrm{a}$ acts as an electron acceptor towards the ferrocene building block of $\mathbf{4 a}$.

Electronic spectra of $\mathbf{4 a}$ are dominated by two absorptions at 660 and $446 \mathrm{~nm}$ in dichloromethane (Fig. 4). The lower energy 
Table 1

Crystal and intensity collection data for $\mathbf{3 b}$ and $\mathbf{4 a}$.

\begin{tabular}{|c|c|c|}
\hline & 3b & $4 a$ \\
\hline Formula weight & 351.44 & 459.46 \\
\hline Chemical formula & $\mathrm{C}_{19} \mathrm{H}_{22} \mathrm{Ru}$ & $\mathrm{C}_{19} \mathrm{H}_{21} \mathrm{Cl}_{3} \mathrm{FeTi}$ \\
\hline Crystal system & Monoclinic & Triclinic \\
\hline Space group & $\mathrm{P} 2_{1} / \mathrm{c}$ & $\rho \overline{1}$ \\
\hline$a(A)$ & $14.0392(3)$ & $6.8296(6)$ \\
\hline$b(A)$ & $11.3396(3)$ & $11.0008(11)$ \\
\hline$c(A)$ & $9.5540(2)$ & $12.3892(12)$ \\
\hline$\alpha(0)$ & - & $83.369(8)$ \\
\hline$\beta(0)$ & $96.665(6)$ & $83.792(7)$ \\
\hline$\gamma\left({ }^{\circ}\right)$ & $-\quad: \quad$ & $88.820(8)$ \\
\hline$V\left(A^{3}\right)$ & $1510.71(6)$ & $919.13(15)$ \\
\hline$\rho_{\text {catc }}\left(\mathrm{g} \mathrm{cm}^{-3}\right)$ & 1.545 & 1.660 \\
\hline$F(000)$ & 720 & 468 \\
\hline Crystal dimensions (mm) & $0.48 \times 0.48 \times 0.34$ & $0.3 \times 0.2 \times 0.2$ \\
\hline$Z$ & 4 & 2 \\
\hline $\begin{array}{l}\text { Maximum and minimum } \\
\text { transmission }\end{array}$ & $1.00000,0.75168$ & $1.00000,0.94954$ \\
\hline Absorption coefficient $\left(\lambda, \mathrm{mm}^{-1}\right)$ & 1.025 & 1.657 \\
\hline Scan range $\left({ }^{\circ}\right)$ & $2.92-26.00$ & $3.00-26.00$ \\
\hline Index ranges & $\begin{array}{l}-17 \leqslant h \leqslant 16 \\
-10 \leqslant k \leqslant 13 \\
-10 \leqslant l \leqslant 11\end{array}$ & $\begin{array}{l}-8 \leqslant h \leqslant 8 \\
-13 \leqslant k \leqslant 13 \\
-15 \leqslant l \leqslant 15\end{array}$ \\
\hline Total reflections & 7900 & 9218 \\
\hline Unique reflections & 2945 & 3616 \\
\hline$R_{\text {int }}$ & 0.0246 & 0.0190 \\
\hline Data/restraints/parameters & $2945 / 0 / 181$ & $3616 / 0 / 217$ \\
\hline Goodness-of-fit on $F^{2}$ & 1.077 & 1.047 \\
\hline$R_{1}^{\mathrm{a}} w R_{2}^{\mathrm{a}}[\ell 2 \sigma(l)]$ & $0.0356,0.0975$ & $0.0333,0.0890$ \\
\hline$R_{1}^{\mathrm{a}}, w R_{2}^{\mathrm{a}}$ (all datä) & $0.0470,0.1024$ & $0.0421,0.0941$ \\
\hline $\begin{array}{l}\text { Largest difference in peak and } \\
\text { hole peak in final Fourier map } \\
\left(\mathrm{e} A^{-3}\right)\end{array}$ & $1.404,-0.591$ & $0.694,-0.649$ \\
\hline
\end{tabular}

${ }^{\mathrm{a}} R_{1}=\left[\sum\left(|| F_{\mathrm{o}}|-| F_{\mathrm{c}} \mid\right) / \sum\left|F_{\mathrm{o}}\right|\right)$

$w R_{2}=\left[\sum\left(w\left(F_{0}^{2}-F_{\mathrm{c}}^{2}\right)^{2}\right) / \sum\left(w F_{\mathrm{o}}^{4}\right)\right]^{1 / 2} \cdot S=\left[\sum w\left(F_{\mathrm{o}}^{2}-F_{\mathrm{c}}^{2}\right)^{2}\right] /(n-p)^{1 / 2} . N$, number of reflections, $p$, parameters used.

bands exhibit positive solvatochromism and shift to 678 and $459 \mathrm{~nm}$ in the more polar $1,2-\mathrm{C}_{2} \mathrm{H}_{4} \mathrm{Cl}_{2} /\left[{ }^{n} \mathrm{Bu}_{4} \mathrm{~N}\right] \mathrm{PF}_{6}$ supporting electrolyte of spectroelectrochemical experiments. This is indicative of a more polar excited state. Molar extinction coefficients $\varepsilon$ of 1060 and $1850 \mathrm{I} \mathrm{mol}^{-1} \mathrm{~cm}^{-1}$ were measured in dichloromethane. The band at 446 (dichloromethane) or $459 \mathrm{~nm} \quad\left(1,2-\mathrm{C}_{2} \mathrm{H}_{4} \mathrm{Cl}_{2}\right.$ l $\left[{ }^{n} \mathrm{Bu}_{4} \mathrm{~N}\right] \mathrm{PF}_{6}$ ) is characteristic of a $\mathrm{CpTiCl}_{3}$-type chromophore (c.f., $\lambda_{\text {tmax }}=445 \mathrm{~nm}$ for $\left(\eta^{5}-\mathrm{C}_{5} \mathrm{Me}_{4} \mathrm{Ph}\right) \mathrm{TiCl}_{3}$ [15]). The low-energy band, however, has neither precedence in $\mathrm{Cp}^{\mathrm{R}} \mathrm{TiCl}_{3}\left(\mathrm{Cp}^{\mathrm{R}}=\eta^{5}-\mathrm{C}_{5} \mathrm{H}_{4} \mathrm{R}\right.$, $\mathrm{R}=$ single bonded organic group) systems nor in ferrocenes. We therefore assign this band to a charge-transfer absorption from the electron-rich ferrocene to the electron-poor half-sandwich titanium site.

In order to probe for this assignment the changes of the electronic spectra of $\mathbf{4 a}$ upon reduction to its associated radical anion $\mathbf{4 a ^ { - - }}$ and upon oxidation to its radical cation $\mathbf{4} \mathbf{a}^{++}$were investigated.

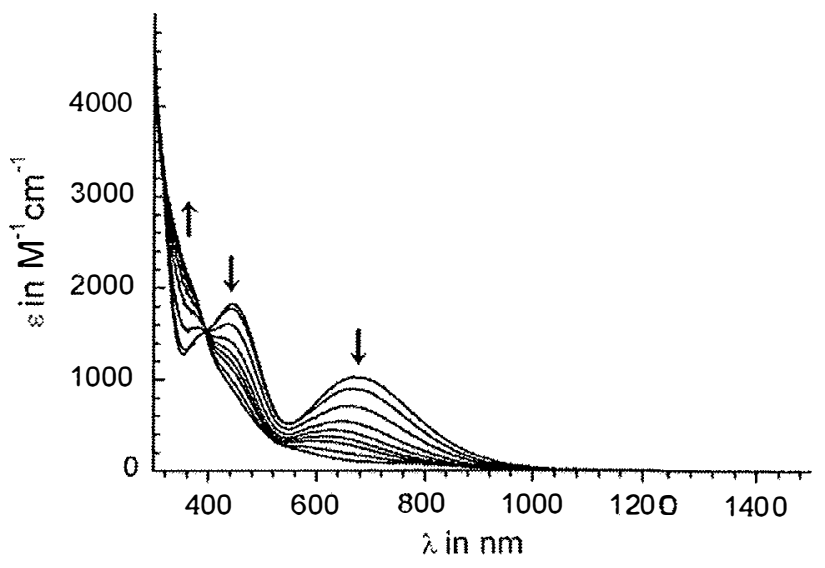

Fig. 4. Spectroscopic changes upon reduction of $4 a\left(1,2-\mathrm{C}_{2} \mathrm{H}_{4} \mathrm{Cl}_{2} /\left[{ }^{n} \mathrm{Bu}_{4} \mathrm{~N}\right] \mathrm{PF} \mathrm{F}_{6}\right)$ in an OTTLE cell.

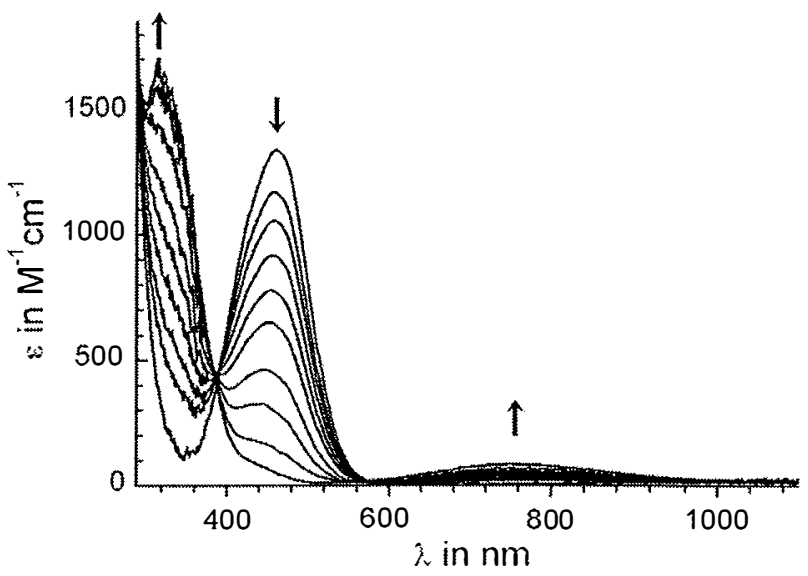

Fig. 5. Spectroscopic changes upon reduction of $\left.\mathrm{Cp}^{*} \mathrm{TiCl}_{3}\left(1,2-\mathrm{C}_{2} \mathrm{H}_{4} \mathrm{Cl}_{2} / l^{n} \mathrm{Bu}_{4} \mathrm{~N}\right] \mathrm{PF}_{6}\right)$ in an OTTLE cell.

Upon reduction the low-energy charge-transfer band and the $459 \mathrm{~nm}$ absorption assigned to the $\mathrm{CpTiCl}_{3}$ chromophore disappeared and were replaced by a very weak band at $774 \mathrm{~nm}$ $\left(\varepsilon=65 \mathrm{I} \mathrm{mol}^{-1} \mathrm{~cm}^{-1}\right.$. Fig. 4). Very similar results were obtained for the in situ reduction of $\mathrm{Cp}^{*} \mathrm{TiCl}_{3}$ (Fig. 5). In particular, the $460 \mathrm{~nm}$ band vanished and was replaced by a weak low-energy band at $751 \mathrm{~nm}\left(\varepsilon=601 \mathrm{~mol}^{-1} \mathrm{~cm}^{-1}\right)$ and a more intense band at $320 \mathrm{~nm}\left(\varepsilon=1650 \mathrm{I} \mathrm{mol}^{-1} \mathrm{~cm}^{-1}\right)$. The low-energy feature in the electronic spectrum of $4 \mathbf{a}^{-}$is thus a genuine absorption of the reduced $\mathrm{Cp}^{R} \mathrm{TiCl}_{3}{ }^{--}$system.
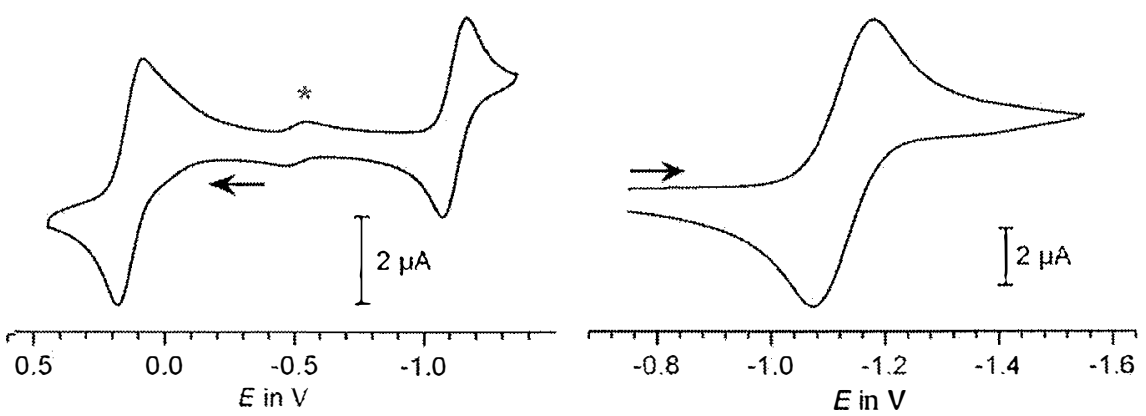

Fig. 3. Cyclic voltammogram of $4 \mathrm{a}$ (left) and $\mathrm{Cp}^{*} \mathrm{TiCl}_{3}$ (right), for comparison, $\left(10^{-3} \mathrm{M}\right.$ solution in dichloromethane at $25^{\circ} \mathrm{C}$ with [" $\left.\mathrm{Bu}_{4} \mathrm{~N}\right] \mathrm{PF} 6\left(0.1 \mathrm{M}^{\circ}\right)$ as supporting electrolyte, scan rate $\left.0.10 \mathrm{~V} \mathrm{~s}^{-1}\right)$; the asterisk marks an impurity. All potentials are referenced to the $\left[\mathrm{FcH} / \mathrm{FcH} \mathrm{F}^{+}\right]$redox couple $\left(\mathrm{FcH}=\left(r^{5}-\mathrm{C}_{5} \mathrm{H}_{5}\right)_{2} \mathrm{Fe}\right)$ with $E_{0}=0.00 \mathrm{~V}[13]$. 


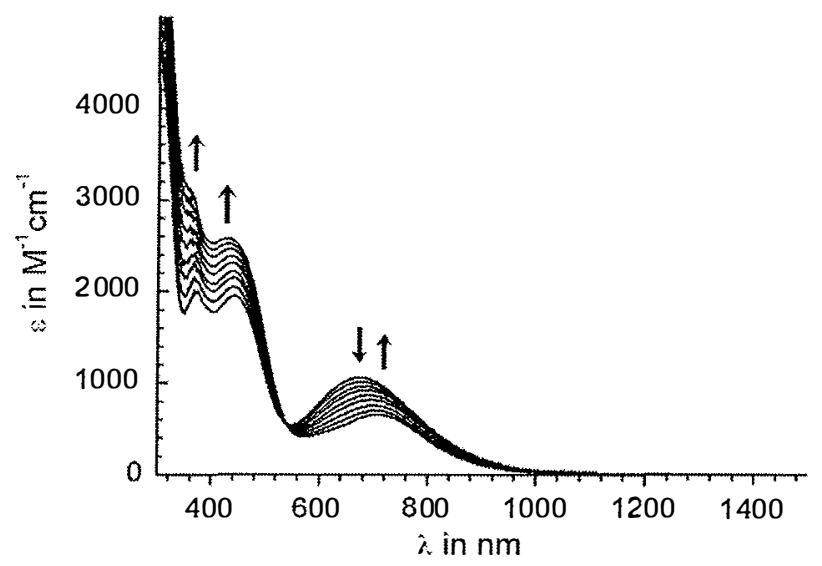

Fig. 6. Spectroscopic changes upon oxidation of $4 a\left(1,2-\mathrm{C}_{2} \mathrm{H}_{4} \mathrm{Cl}_{2} /\left[{ }^{n} \mathrm{Bu}_{4} \mathrm{~N}\right] P \mathrm{PF}_{6}\right)$ in an OTTLE cell.

Oxidation of $\mathbf{4 a}$ to $4 \mathbf{a}^{+}$causes the emergence of a new absorption at $710 \mathrm{~nm}\left(\varepsilon=650 \mathrm{Imol}^{-1} \mathrm{~cm}^{-1}\right)$ that we ascribe to the oxidized ferrocenium chromophore (Fig. 6). A further, more intense band is observed at $430 \mathrm{~nm}$ and can be deconvoluted into separate absorptions at 450 and $371 \mathrm{~nm}$, respectively. The $450 \mathrm{~nm}$ component with an estimated $\varepsilon$ of $2300 \mathrm{Imol}^{-1} \mathrm{~cm}^{-1}$ is most probably due to the half-sandwich titanium subunit of $\mathbf{4 a}^{\mathbf{a}^{+}}$. The blue shift of this band by $9 \mathrm{~nm}$ upon oxidation is a token of the decreasing electron density at the half-sandwich titanocene site upon oxidation of the attached ferrocene building block [15]. Along with the disappearance of the low-energy charge-transfer band in 4a upon oxidation and reduction provides further evidence for some transmittance of electronic information between the joined ferrocene and $\mathrm{CpTiCl}_{3}$ subunits of $4 \mathrm{a}$ via the fulvalenediyl bridge.

\section{Conclusion}

The consecutive preparation of fulvalenediyl-bridged early-late heterobimetallics has been achieved by treatment of monolithiated metallocenes (ferrocene, ruthenocene) with 2,3,4,5-tetramethylcyclopent-2-enone followed by addition of ${ }^{n} \mathrm{BuLi}$ and $\mathrm{TiCl}_{4}$, respectively. In molecules $\left[\left(\eta^{5}-\mathrm{C}_{5} \mathrm{H}_{5}\right)\left(\left(\mu-\eta^{5}: \eta^{5}-\mathrm{C}_{5} \mathrm{H}_{4}-\mathrm{C}_{5} \mathrm{Me}_{4}\right) \mathrm{TiCl}_{3}\right) \mathrm{M}\right]$ $(\mathrm{M}=\mathrm{Fe}, \mathrm{Ru})$ early and late transition metals are brought in close proximity to each other as it could be demonstrated by single $X$ ray structure determination ( $\mathrm{Fe}-\mathrm{Ti}$ separation of 5.3076(8) $\AA$ ). Electrochemical studies revealed the mutual influence of the subunits by the anodic shift of the ferrocene-based half-wave potential, when compared to those of ferrocene itself and biferrocene, respectively. Further evidence for such interactions comes from the fairly intense low-energy band of $\mathbf{4 a}$ and $\mathbf{4 b}$ that has no precedent in the isolated mononuclear counterparts and is assigned as a $\mathrm{Fe} \rightarrow \mathrm{Ti}$ charge-transfer absorption. In keeping with this assignment, it disappears when the ferrocene moiety is oxidized or the cyclopentadienyl $\mathrm{TiCl}_{3}$ building block is reduced. A weak low-energy absorption of reduced $4 \mathbf{a}^{-}$can be traced to the reduced $\mathrm{CpTiCl}_{3}{ }^{-{ }^{--}}$subunit as is shown by the comparison with electro-generated $\mathrm{Cp}^{*} \mathrm{TiCl}_{3}{ }^{-}$.

\section{Experimental}

\subsection{General data}

All reactions were carried out under an atmosphere of nitrogen using standard Schlenk techniques. Toluene, tetrahydrofuran, $n$ pentane and $n$-hexane were purified by distillation from sodium/ benzophenone ketyl; dichloromethane was purified by distillation from calcium hydride. Celite (purified and annealed, Erg. B.6, Riedel de Haen) was used for filtrations.

\subsection{Instruments}

${ }^{1} \mathrm{H}$ NMR spectra were recorded with a Bruker Avance 250 spectrometer operating at $250.130 \mathrm{MHz}$ in the Fourier transform mode: ${ }^{13} \mathrm{C}\left\{{ }^{1} \mathrm{H}\right\}$ NMR spectra were recorded at $62.860 \mathrm{MHz}$. Chemical shifts are reported in $\delta$ units (parts per million) downfield from tetramethylsilane with the solvent as reference signal $\left({ }^{1} \mathrm{H}\right.$ NMR: $\mathrm{CDCl}_{3}$ (99.8\%), $\delta=7.26 .{ }^{13} \mathrm{C}\left\{{ }^{1} \mathrm{H}\right\}$ NMR: $\mathrm{CDCl}_{3}$ (99.8\%), $\left.\delta=77.16\right)$. The abbreviation $p t$ in the ${ }^{1} \mathrm{H}$ NMR spectra corresponds to pseudo-triplet. Microanalyses were performed with the $\mathrm{C}_{1} \mathrm{H}, \mathrm{N}$ analyzer FLASHEA 1112 Series (Thermo company). The equipment for voltammetric and spectroelectrochemical studies and the conditions employed in this work were described elsewhere [16]. UV/Vis/ NIR spectra were recorded on an Omega20 spectrometer of Bruins Instruments.

\subsection{Reagents}

1-Bromoferrocene [17a], 1-iodoruthenocene [17b], and 3a $[4 \mathrm{~b}, 5]$ were prepared according to published procedures. All other chemicals were purchased from commercial suppliers and were used as received.

\subsubsection{Synthesis of $\left[\left(\eta^{5}-\mathrm{C}_{5} \mathrm{H}_{5}\right)\left(\eta^{5}-\mathrm{C}_{5} \mathrm{H}_{4}-\mathrm{C}_{5} \mathrm{Me} \mathrm{C}_{4}\right) \mathrm{Ru}\right](\mathbf{3 b})$}

To $2.68 \mathrm{~g}(7.51 \mathrm{mmol})$ of iodoruthenocene dissolved in $40 \mathrm{~mL}$ of tetrahydrofuran were added $3 \mathrm{~mL}(7.52 \mathrm{mmol})$ of ${ }^{n} \mathrm{BuLi}$ at $-80^{\circ} \mathrm{C}$ in a single portion. After $1 \mathrm{~h}$ of stirring at this temperature, $1.12 \mathrm{~mL}$ $(7.53 \mathrm{mmol})$ of 2 were added in a single portion by syringe. The reaction solution was warmed to ambient temperature and stirred for $1 \mathrm{~h}$. Afterward, $20 \mathrm{~mL}$ of a concentrated aqueous solution of $\left[\mathrm{NH}_{4}\right] \mathrm{Cl}$ was used for quenching the reaction and stirring was continued for $30 \mathrm{~min}$. The separated organic phase was then treated with $2 \mathrm{~g}(10.51 \mathrm{mmol})$ of para-toluenesulfonic acid monohydrate and stirred for another $30 \mathrm{~min}$. The reaction mixture was extracted with diethyl ether ( 4 times, $50 \mathrm{~mL}$ each) and all volatiles were removed under reduced pressure. The title compound could be obtained by chromatography on silica gel and $n$-hexane as eluent. Yield: $2.07 \mathrm{~g}$ ( $5.89 \mathrm{mmol}, 78 \%$ based on iodoruthenocene).

Anal. Calc. for $\mathrm{C}_{19} \mathrm{H}_{22} \mathrm{Ru}$ (351.45): $\mathrm{C}, 64.93 ; \mathrm{H}$ 6.31. Found: $\mathrm{C}$, 65.05; $\mathrm{H}, 6.36 .{ }^{1} \mathrm{H}$ NMR $\left(\delta, \mathrm{CDCl}_{3}\right): 1.10\left(\mathrm{~d},{ }^{3} \mathrm{~J}_{\mathrm{HH}}=7.6 \mathrm{~Hz}, 3 \mathrm{H}\right.$, $\left.\mathrm{CH}_{3}\right), 1.78\left(\mathrm{~s}, 3 \mathrm{H}, \mathrm{CH}_{3}\right), 1.90\left(\mathrm{~d},{ }^{4} J_{\mathrm{HH}}=1.0 \mathrm{~Hz}, 3 \mathrm{H}, \mathrm{CH}_{3}\right), 1.94(\mathrm{~d}$, $\left.{ }^{4} J_{\mathrm{HH}}=1.7 \mathrm{~Hz}, 3 \mathrm{H}, \mathrm{CH}_{3}\right) 2.76$ (ddd, ${ }^{3} \int_{\mathrm{HH}}=7.6 \mathrm{~Hz},{ }^{4} \int_{\mathrm{HH}}=1.7 \mathrm{~Hz}$, $\left.4 J_{\mathrm{HH}}=1.0 \mathrm{~Hz}, 1 \mathrm{H}, \mathrm{CH}_{3}\right), 4.50\left(\mathrm{~s}, 5 \mathrm{H}, \mathrm{C}_{5} \mathrm{H}_{5}\right), 4.57\left(\mathrm{pt}, J_{\mathrm{HH}}=1.4 \mathrm{~Hz}\right.$, $\left.2 \mathrm{H}, \mathrm{C}_{5} \mathrm{H}_{4}\right), 4.65-4.70\left(\mathrm{~m}, 1 \mathrm{H}, \mathrm{C}_{5} \mathrm{H}_{4}\right), 4.73-4.78\left(\mathrm{~m}, 1 \mathrm{H}, \mathrm{C}_{5} \mathrm{H}_{4}\right)$. ${ }^{13} \mathrm{C}\left\{{ }^{1} \mathrm{H}\right\}$ NMR $\left(\delta, \mathrm{CDCl}_{3}\right): 11.4\left(\mathrm{CH}_{3}\right), 12.2\left(\mathrm{CH}_{3}\right), 13.3\left(\mathrm{CH}_{3}\right), 16.5$ $\left(\mathrm{CH}_{3}\right), 51.4\left(\mathrm{C}^{\mathrm{i}} / \mathrm{C}_{5} \mathrm{H}_{4}\right), 69.9\left(\mathrm{C}^{\beta} / \mathrm{C}_{5} \mathrm{H}_{4}\right), 71.2\left(\mathrm{C}_{5} \mathrm{H}_{5}\right), 71.8\left(\mathrm{C}^{\alpha} / \mathrm{C}_{5} \mathrm{H}_{4}\right)$, $87.2\left(\mathrm{CHCH}_{3}\right), 135.3\left(\mathrm{CCH}_{3}\right), 136.8\left(\mathrm{CCH}_{3}\right), 137.8\left(\mathrm{CCH}_{3}\right), 140.0(\mathrm{Cl}$ $\left.\mathrm{C}_{5} \mathrm{H}\left(\mathrm{CH}_{3}\right)_{4}\right)$. Mp. $68^{\circ} \mathrm{C}$.

4.3.2. Synthesis of $\left[\left(\eta^{5}-C_{5} H_{5}\right)\left(\left(\mu-\eta^{5}: \eta^{5}-C_{5} H_{4}-C_{5} M_{4}\right) T_{i C l}\right) F e\right](4 a)$

To $1.15 \mathrm{~g}(3.61 \mathrm{mmol})$ of $3 \mathrm{a}$ dissolved in $50 \mathrm{~mL}$ of diethyl ether were added $1.45 \mathrm{~mL}(3.61 \mathrm{mmol})$ of ${ }^{n} \mathrm{BuLi}$ at $-30^{\circ} \mathrm{C}$ in a single portion. After $2 \mathrm{~h}$ of stirring at ambient temperature the lithium salt precipitated and a solution of $0.34 \mathrm{~mL}(3.13 \mathrm{mmol})$ of titanium tetrachloride in $10 \mathrm{~mL}$ of toluene was added dropwise to the reaction mixture, whereby the color changed from orange to dark green. After stirring over night with $8.90 \mathrm{~g}(3.20 \mathrm{mmol})$ of $\mathrm{PbCl}_{2}$ all volatiles were removed in oil-pump vacuum and the dark green residue was dissolved in $40 \mathrm{~mL}$ of dichloromethane and was filtered through a pad of Celite. The obtained solution was concentrated $(10 \mathrm{~mL})$ under reduced pressure and layered with $n$-hexane, whereby a dark green solid crystallized at $-30^{\circ} \mathrm{C}$. Impurities of 
ferrocene could be removed by sublimation in oil-pump vacuum. Yield: $730 \mathrm{mg}$ ( $1.55 \mathrm{mmol}, 50 \%$ based on $3 \mathrm{a}$ ).

Anal. Calc. for $\mathrm{C}_{19} \mathrm{H}_{21} \mathrm{Cl}_{3} \mathrm{FeTi} \times 1 / 5 \mathrm{CH}_{2} \mathrm{Cl}_{2}$ (476.43): $\mathrm{C}, 48.40 ; \mathrm{H}$ 4.53. Found: $\mathrm{C}, 48.31 ; \mathrm{H}, 4.69 .{ }^{1} \mathrm{H}$ NMR $\left(\delta, \mathrm{CDCl}_{3}\right): 2.41(\mathrm{~s}, 6 \mathrm{H}$, $\left.\mathrm{CH}_{3}\right), 2.70\left(\mathrm{~s}, 6 \mathrm{H}, \mathrm{CH}_{3}\right), 4.19\left(\mathrm{~s}, 5 \mathrm{H}, \mathrm{C}_{5} \mathrm{H}_{5}\right), 4.49\left(\mathrm{pt}, J_{\mathrm{HH}}=1.8 \mathrm{~Hz}\right.$, $\left.4 \mathrm{H}, \mathrm{H}^{\alpha} / \mathrm{C}_{5} \mathrm{H}_{4}\right), 4.68\left(\mathrm{pt}, J_{\mathrm{HH}}=1.8 \mathrm{~Hz}, 4 \mathrm{H}, \mathrm{H}^{\beta} / \mathrm{C}_{5} \mathrm{H}_{4}\right), 5.29\left(\mathrm{CH}_{2} \mathrm{Cl}_{2}\right)$. ${ }^{13} \mathrm{C}\left\{{ }^{1} \mathrm{H}\right\} \operatorname{NMR}\left(\delta, \mathrm{CDCl}_{3}\right): 14.8\left(\mathrm{CH}_{3}\right), 16.7\left(\mathrm{CH}_{3}\right), 53.1\left(\mathrm{CH}_{2} \mathrm{Cl}_{2}\right)$, $68.1\left(\mathrm{C}^{\mathrm{i}} / \mathrm{C}_{5} \mathrm{H}_{4}\right), 69.6\left(\mathrm{C}^{\beta} / \mathrm{C}_{5} \mathrm{H}_{4}\right), 69.9\left(\mathrm{C}_{5} \mathrm{H}_{5}\right), 70.1\left(\mathrm{C}^{\alpha} / \mathrm{C}_{5} \mathrm{H}_{4}\right), 135.1$ $\left(\mathrm{C}_{5}\left(\mathrm{CH}_{3}\right)_{4}\right), 140.0\left(\mathrm{C}_{5}\left(\mathrm{CH}_{3}\right)_{4}\right), 140.9\left(\mathrm{C}^{\mathrm{i}} / \mathrm{C}_{5}\left(\mathrm{CH}_{3}\right)_{4}\right)$.

\subsubsection{Synthesis of $\left[\left(\eta^{5}-\mathrm{C}_{5} \mathrm{H}_{5}\right)\left(\left(\mu-\eta^{5}: \eta^{5}-\mathrm{C}_{5} \mathrm{H}_{4}-\mathrm{C}_{5} \mathrm{Me}_{4}\right) \mathrm{TiCl} \mathrm{Cl}_{3}\right) \mathrm{Ru}\right]$ (4b)}

Compound $\mathbf{4 b}$ was synthesized by the same reaction protocol as described for the preparation of $4 \mathbf{a}$. Thus, $1.05 \mathrm{~g}(2.98 \mathrm{mmol})$ of $\mathbf{3 b}$ were reacted with $1.19 \mathrm{~mL}(2.98 \mathrm{mmol})$ of ${ }^{n} \mathrm{BuLi}$ and $0.33 \mathrm{~mL}$ $(3.04 \mathrm{mmol})$ of titanium tetrachloride. Please, notice that workup with $\mathrm{PbCl}_{2}$ is not necessary. The title complex was isolated as a purple solid. Yield: $496 \mathrm{mg}$ ( $0.98 \mathrm{mmol}, 33 \%$ based on $\mathbf{3 b}$ ).

Anal. Calc. for $\mathrm{C}_{19} \mathrm{H}_{21} \mathrm{Cl}_{3}$ RuTi (504.67): $\mathrm{C}, 45.22 ; \mathrm{H}$ 4.19. Found: C, 45.46: $\mathrm{H}, 4.32 .{ }^{1} \mathrm{H} \mathrm{NMR}\left(\delta, \mathrm{CDCl}_{3}\right): 2.37\left(\mathrm{~s}, 6 \mathrm{H}, \mathrm{CH}_{3}\right), 2.60(\mathrm{~s}, 6 \mathrm{H}$, $\left.\mathrm{CH}_{3}\right), 4.58\left(\mathrm{~s}, 5 \mathrm{H}, \mathrm{C}_{5} \mathrm{H}_{5}\right), 4.75\left(\mathrm{pt}, J_{\mathrm{HH}}=1.7 \mathrm{~Hz}, 4 \mathrm{H}, \mathrm{H}^{\alpha} / \mathrm{C}_{5} \mathrm{H}_{4}\right), 4.99$ $\left(\mathrm{pt}, J_{\mathrm{HH}}=1.7 \mathrm{~Hz}, 4 \mathrm{H}, \mathrm{H}^{\beta} / \mathrm{C}_{5} \mathrm{H}_{4}\right) .{ }^{13} \mathrm{C}\left\{{ }^{1} \mathrm{H}\right\} \operatorname{NMR}\left(\delta, \mathrm{CDCl}_{3}\right): 15.0$ $\left(\mathrm{CH}_{3}\right), 16.7\left(\mathrm{CH}_{3}\right), 70.2\left(\mathrm{C}^{\mathrm{i}} / \mathrm{C}_{5} \mathrm{H}_{4}\right), 71.2\left(\mathrm{C}^{\beta} / \mathrm{C}_{5} \mathrm{H}_{4}\right), 72.2\left(\mathrm{C}^{\alpha} / \mathrm{C}_{5} \mathrm{H}_{4}\right)$, $72.7\left(\mathrm{C}_{5} \mathrm{H}_{5}\right), 135.7\left(\mathrm{C}_{5}\left(\mathrm{CH}_{3}\right)_{4}\right), 139.0\left(\mathrm{C}_{5}\left(\mathrm{CH}_{3}\right)_{4}\right), 139.9\left(\mathrm{C}^{\mathrm{i}} / \mathrm{C}_{5}\left(\mathrm{CH}_{3}\right)_{4}\right)$.

\subsection{Crystal structure determination}

The crystal and intensity collection data for $\mathbf{3 b}$ and $\mathbf{4 a}$ are summarized in Table 1. All data were collected on a Oxford Gemini $S$ diffractometer with graphite monochromatized Mo $K \alpha$ radiation $(\lambda=0.71073 \AA)$ at $100 \mathrm{~K}(3 \mathbf{b}, \mathbf{4 a})$ using oil-coated shock-cooled crystals [18]. The structures were solved by direct methods using SHELXs-97 [19] and refined by full-matrix least-square procedures on $F^{2}$ using sHelxL-97 [20]. All non-hydrogen atoms were refined anisotropically and a riding model was employed in the refinement of the hydrogen atom positions.

\section{Supplementary material}

CCDC 729388 and 729387 contains the supplementary crystallographic data for this paper. These data can be obtained free of charge from The Cambridge Crystallographic Data Centre via http://www.ccdc.cam.ac.uk/data_request/cif.

\section{Acknowledgements}

We are grateful to the Deutsche Forschungsgemeinschaft and the Fonds der Chemischen Industrie for generous financial support.

\section{References}

[1] (a) H. Hilbig, F.H. Köhler, K. Mörtl, J. Organometal. Chem. 627 (2001) 71; (b) E.G. Perevalova, O.A. Nesmeyanova, Dokl. Akad. Nauk. SSSR 132 (1960) 1093:

(c) M.D. Rausch, J. Am. Chem. Soc. 82 (1960) 2080;

(d) F.L. Hedberg, H. Rosenberg, J. Am. Chem. Soc. 91 (1969);

(e) M.D. Rausch, R.F. Kovar, C.G. Kraihanzel, J. Am. Chem. Soc. 91 (1969) 1259;

(f) G.H. Brown, T.J. Meyer, D.O. Cowan, C. LeVanda, F. Kaufmann, P.V. Roling M.D. Rausch, Inorg. Chem. 14 (1975) 506;

(g) E.W. Neuse, H. Rosenberg, Metallocene Polymers, Marcel Dekker, New York, 1970 (Chapter 3);

(h) D.S. Brown, M.-H. Delville, K.P.C. Vollhardt, D. Astruc, Organometallics 15 (1996) 2360;

(i) D. Obendorf, H. Schottenberger, C. Rieker, Organometallics 10 (1991) 1293.

[2] (a) R. Boese, J.K. Cammack, A.J. Matzger, K.P. William, B. Tolman, K.P.C Vollhardt, T.W. Weidman. J. Am. Chem. Soc. 119 (1997) 6757;

(b) L. Zhang, N. Xiao, Q. Xu, J. Sun. J. Chen. Organometallics 24 (2005) 5807; (c) M. Mitani, K. Oouchi, M. Hayakawa, T. Yamada, T. Mukaiyama, Macromol. Chem. Phys. 197 (1996) 1815.

[3] (a) J.J. Morris, B.C. Noll, G.W. Honeyman, C.T. O'Hara, A.R. Kennedy, R.E. Mulvey, K.W. Henderson, Chem. Eur. J. 13 (2007) 4418; (b) I. Tomita, M. Ueda, Macromol. Symp. 209 (2004) 217;

(c) J.-C. Lee, A. Nishio, I. Tomita, T. Endo, Macromolecules 30 (1997) 5205: (d) R. Packheiser, P. Ecorchard, T. Rüffer, H. Lang, Chem. Eur. J. 14 (2008) 4948;

(e) S. Lanza, F. Loiseau, G. Tresoldi, S. Serroni, S. Campagna, Inorg. Chim. Acta 360 (2007) 1929:

(f) R. Packheiser, A. Jakob, P. Ecorchard, B. Walfort, H. Lang, Organometallics 27 (2008) 1214;

(g) A. Cucos, N. Avarvari. M. Andruh, Y. Journaux, A. Müller, M. Schmidtmann, Eur. J. Inorg. Chem. (2006) 903:

(h) R. Packheiser, P. Ecorchard, T. Rüffer, H. Lang, Organometallics 27 (2008) 3534 .

[4] (a) J.M. Manriquez, M.D. Ward, W.M. Reiff, J.C. Calabrese, N.L. Jones, P.J. Carroll, E.E. Bunel, J.S. Miller, J. Am. Chem. Soc. 117 (1995) 6182;

(b) S. Wan, M.J. Begley, P. Mountford, J. Organomet. Chem. 489 (1995) C28;

(c) I.M. Piglosiewicz, S. Kraft, R. Beckhaus, D. Haase, W. Saak, Eur. J. Inorg. Chem. (2005) 938;

(d) O.Š. Miljanić, K.P.C. Vollhardt, M.J. West, Synthesis 19 (2005) 3373;

(e) J. Ni, Q. Zhou, D.K. Canseco, T.R. Calhoun, A.R. Graham, K.L. Carreras, C.N. Schultz, Inorg. Chim. Acta 309 (2000) 23;

(f) T.-Y. Dong, H.-Y. Lin, S.-F. Lin, C.-C. Huang. Y.-S. Wen, L. Lee, Organometallics 27 (2008) 555:

(g) S. Santi, L. Orian, C. Durante, E.Z. Bencze, A. Bisello, A. Donoli, A. Ceccon, F. Benetollo, L. Crociati, Chem. Eur. J. 13 (2007) 7933

(h) B. Quillian. Y. Wang. C.S. Wannere, P. Wei. P. Ragué Schleyer, G.H. Robinson, Angew. Chem., Int. Ed. 46 (2007) 1836;

(i) T.-Y. Dong, M.-C. Lin, S.-W. Chang, C.-C. Ho, S.-F. Lin, L. Lee, J. Organomet. Chem. 692 (2007) 2324;

(j) S. Santi, L. Orian, C. Durante, A. Bisello, F. Benetollo, L. Crociani, P. Ganis, A. Ceccon. Chem. Eur. J. 13 (2007) 1955;

(k) C.A. Nijhuis, K.A. Dolatowska, B.J. Ravoo, J. Huskens, D.N. Reinhoudt, Chem. Eur. J. 13 (2007) 69 :

(I) S. Köcher, G. P.M. Klink, G. Koten, H. Lang, J. Organomet. Chem. 691 (2006) 3319:

(m) J. Lin, B. Wang, S. Xu, H. Song, J. Organomet. Chem. 691 (2006) 2528

(n) Y. Yu, A.D. Bond, P.W. Leonard, K.P.C. Vollhardt, G.D. Whitener, Angew. Chem., Int. Ed. 45 (2006) 179;

(o) T.-Y. Dong, S.-W. Chang, S.-F. Lin, M.-C. Lin, Y.-S. Wen, L. Lee, Organometallics 25 (2006) 2018;

(p) R. Warratz, G. Peters, F. Studt, R.-H. Römer, F. Tuczek, Inorg. Chem. 45 (2006) 2531;

(q) A. Nafady, T.T. Chin, W.E. Geiger, Organometallics 25 (2006) 1654;

(r) B. Li, B. Wang, S. Xu, X. Zhou, H. Song, Organometallics 25 (2006) 1158;

(s) G. Laus, C.E. Strasser, M. Holzer, K. Wurst, G. Piirstinger, K.-H. Ongania, M Rauch, G. Bonn, H. Schottenberger, Organometallics 24 (2005) 6085:

(t) T. Mochida, K. Takazawa, H. Matsui, M. Takahashi, M. Takeda, M. Sato, Y. Nishio, K. Kajita, H. Mori, Inorg. Chem. 44 (2005) 8628;

(u) H. Schottenberger, M. Buchmeister, O. Elsner, E. Ernst, J. Reussner, W. Neissl, H. Angleitner, US 5.521.265, 1996.

(v) D.R. Talham, D.O. Cowan, Organometallics 6 (1987) 932;

(w) M. Tamm, T. Bannenberg, K. Baum, R. Fröhlich, T. Steiner, T.M. Friedrichsen, J. Heck, Eur. J. Inorg. Chem. (2000) 1161.

[5] P. Scott, U. Rief, J. Diebold, H.H. Brintzinger, Organometallics 12 (1993) 3094.

[6] H. Plenio, Organometallics 11 (1992) 1856.

[7] (a) S. Fortier, M.C. Baird, K.F. Preston, J.R. Morton, T. Ziegler, T.J. Jaeger, W.C. Watkins, J.H. MacNeil, K.A. Watson, K. Hensel, Y.L. Page, J.-P. Charland, A.J. Williams, J. Am. Chem. Soc. 113 (1991) 542;

(b) F. de Montigny, G. Argouarch, T. Roisnel, L. Toupet, C. Lapinte, S.C.-F. Lam, C.-H. Tao, V. Wing-Wah, Organometallics 27 (2008) 1912:

(c) C. Bruhn, T. Kügerb, D. Steinborn, Acta Crystallogr., Sect. C 64 (2008) $\mathrm{m} 455$.

[8] (a) T.Y. Dong, D.N. Hendrickson, K. Iwai, M.J. Cohn, S.J. Geib, A.L. Rheingold, H. Sano, I. Motoyama, S. Nakashima, J. Am. Chem. Soc. 107 (1985) 7996:

(b) T. Yuan, D.N. Hendrickson, C.G. Pierpont, M.F. Moore, J. Am. Chem. Soc. 108 (b) T. Yuan,

[9] C. Elschenbroich, J. Plackmeyer, M. Nowotny, A. Behrendt, K. Harms, J. Pebler, O. Burghaus, Chem. Eur. J. 11 (2005) 7427.

[10] C.G. Atwood, W.E. Geiger. J. Am. Chem. Soc. 122 (2000) 5477.

[11] (a) P. Hudeczek, F.H. Köhler, P. Bergerat, O. Kahn, Chem. Eur. J. 4 (1999) 70 (b) H. Hilbig, P. Hudeczek, F.H. Köhler, X. Xie, P. Bergerat, O. Kahn, Inorg Chem. 37 (1998) 4246

[12] T. Weiß, K. Natarajan, H. Lang, R. Holze. J. Electroanal. Chem. 533 (2002) 127.

[13] (a) G. Gritzner, J. Kuta, Pure Appl. Chem. 56 (1984) 461:

(b) H. Strehlow, W. Knoche, H. Schneider, Ber. Bunsenges. Phys. Chem. 77 (1973) 760.

[14] T.-Y. Dong, T.-Y. Lee, S.-H. Lee, G.-H. Lee, S.-M. Peng, Organometallics 13 (1994) 2337.

[15] (a) J.W. Kennedy III, D.R. Boone, D.R. Striplin, Y.-H. Chen, K.B. Hamar, Organometallics 12 (1993) 3671:

(b) J. Pinkas, A. Lyčka, P. Šindelăř, R. Gyepes, V. Varga, J. Kubišta, M. Horáček, K. Mach, J. Mol. Catal. A 257 (2006) 14

[16] J. Maurer, B. Sarkar, B. Schwederski, W. Kaim, R.F. Winter, S. Záliš, Organometallics 25 (2006) 3701.

[17] (a) A.N. Nesmeyanow, W.A. Ssazonowa, V.N. Drosd, Chem. Ber. 93 (1960) 2717:

(b) L. Bednarik, E. Neuse, J. Organomet. Chem. 168 (1979) C8. 
[18] (a) T. Kottke, D.J. Stalke, Appl. Crystallogr. 26 (1993) 615:

(b) T. Kottke, R.J. Lagow. D.J. Stalke. Appl. Crystallogr. 29 (1996) 465;

(c) D. Stalke, Chem. Soc. Rev. 27 (1998) 171
[19] G.M. Sheldrick, Acta Crystallogr., Sect. A 46 (1990) 467.

[20] G.M. Sheldrick, SHELXL-97. Program for Crystal Structure Refinement, University of Göttingen, 1997. 